\title{
News in brief from Statistical Offices
}

\section{Australia \\ Management Changes}

Richard Madden has left the Australian Bureau of Statistics to become Director of the Australian Institute of Health and Welfare. The Institute is an Australian Government statutory authority. Its mission is to "inform the community discussion and to support public policy making on health and welfare issues by coordinating, developing, analysing and disseminating national statistics on the health of Australians and their health and welfare services, and by undertaking and supporting related research analysis".

\section{Austria}

\section{Meetings}

In the framework of TES (Training of European Statisticians), the course "Pilot Surveys for the Service Sector" was held at ÖSTAT's from 26 to 28 February 1996.

From 16 to 17 May 1996, the Conference of the Directors General of EU National Statistical Institutes will be held in Vienna.

An assistance project for the Republic of Bosnia and Herzegovina was organized at the end of January 1996.

With the Austrian entry into the European Union on 1 January 1995, the EU and EUROSTAT working programmes became obligatory. Hence, ÖSTAT has to adapt its statistics to EU requirements. The major adaptation procedures concern the following statistical fields:

- introduction of the EC statistical classification systems (NACE, CPA, PRODCOM),

- adaptation to the concepts of the European System of Integrated Economic Accounts 1995, harmonisation of Gross Social Accounting,

- adaptation to new foreign trade statistics - INTRASTAT,

- work on the new business register,

- preparation of a new concept of data surveys in the production area and a new concept of short-term indices,

- preparatory work for the European Household Panel,

- harmonised European consumer price index - index revision,

- Labour Force Survey and Family Budget Survey,

- adaptation of the structural agricultural survey and of the livestock survey,

- inclusion of migration statistics into the ÖSTAT's Annual Working Programme.

\section{Germany}

\section{Management Changes}

As of 2 October 1995, Mr. Johann Hahlen assumed the post of President of the Federal Statistical Office. Before 
taking charge of the Federal Statistical Office, Mr. Hahlen held the position of Head of the Directorate on "Constitutional Law" in the Federal Ministry of the Interior. His predecessor, Mr. Hans Günther Merck, has retired but will still be active in the cooperation with the newly independent states of the former Soviet Union.

\section{Publications}

The annually published handbook entitled "Zählenkompaß" (Key Data on Germany) provides important data from all fields of German official statistics. The publication, in the convenient pocket book format, offers a spectrum of topical and factual data on the social, economic and cultural life in Germany, and comparative data on countries of the European Union and other industrial countries supplement the outline. Besides the German version, there are also English and Russian versions available, and a translation into French and Spanish is planned. The German edition can be obtained at Verlag Metzler-Poeschi, Verlagsauslieferung Hermann Leins GmbH u. Co. KG, D-72125 Kusterdingen, as well as at all specialized bookshops. Single copies of the foreign language editions can be obtained free of charge at Statistisches Bundesamt, D65180 Wiesbaden.

A translation into German of the World Tourism Organization's (WTO) "Recommendations on Tourism Statistics" has been prepared as a cooperational project between the Federal Statistical Office of Germany, the Swiss Federal Statistical Office and the Central Statistical Office of Austria. This is the short version of the WTO recommendations which have been elaborated in an international conference on Travel and Tourism Statistics in Ottawa, Canada, in
1991 and have been adopted by the United Nations Statistical Commission in March 1993. Single copies of the translation can be obtained against refunding of postage expenses (DM 1,50.in stamps) at Statistisches Bundesamt, D-65180 Wiesbaden.

\section{Kyrgyzstan}

\section{Meetings}

The year 1996 is the 70th Anniversary of the Republic's Statistics. In this context, the National Statistical Committee of Kyrgyzstan is planning to hold a conference on "Statistics in Transition Period (theory and practice)". Many participants will be invited to take part in this conference, including representatives from international organizations, embassies and representative offices accredited in the Republic as well as participants from the CIS Statistical Offices.

\section{Poland}

\section{Management changes}

On 4 January 1996, upon the positive recommendation of the Statistical Council, Mr. Tadeusz Toczynski, 47, was elected President of the Central Statistical Office of Poland.

Mr. Toczynski graduated from the Warsaw School of Planning and Statistics in 1974 and in the same year he started his work in the CSO's Industrial Statistics Division. In the years of 1980-1982 he worked in the ECE Secretariat in Geneva where he was involved in the preparation of statistical information and reports on the Central and Eastern European countries according to in- 
ternational classifications and he was involved also in the preparation of the "Economic Survey for Europe". Back from Geneva, he continued his work at the CSO, becoming soon the Deputy Director of the Industrial Statistics Division and then the Director of the CSO Price Statistics Division. In the years 1990-1992 he was a Vice-President of the CSO responsible, inter alia, for the price statistics, foreign and domestic trade statistics and international cooperation, including contacts with the United Nations and European Union. In the years 1992-1995, he was the President of consulting company Creditreform Polska.

The Prime Minister, upon the recommendation of Mr. Toczynski, appointed four Vice-Presidents of the CSO: Mr. Janusz Witkowski, Mr. Roman Sawinski, Mr. Tadeuz Janusiewicz and Mr. Josef Piskorz.

The Chairman of the Statistical Council is Mr. Franciszek Kubiczek, who in the years 1989-1991 was the President of the Central Statistical Office.

\section{Ukraine}

\section{Statistical legislation}

Two laws, relating to statistics and information, were adopted in SeptemberOctober 1992 in the Ukraine.

The "Law on State Statistics" regulates the legal statistics relations, introduces the primary registration system, defines the powers and functions of the state statistical bodies and creates the basis for introducing the state system of information in Ukraine, which is aimed at obtaining reliable statistics on socio-eco- nomic development of the country and its regions. This is a basic law for all other legislative acts to be adopted.

The Council of Ministers of the Ukraine defines the state policy in the domain of statistics and this policy is being carried out by the Ministry of Statistics, the bodies of state statistics of the autonomous Republic of Crimea, the regions, the districts and cities, which, together with the subordinate agencies, enterprises and organizations, form the system of state statistical bodies of the Ukraine.

The "Law of Information" guarantees the right of citizens of Ukraine to obtain the necessary information and creates the legal basis for information activities. One of the articles of the law defines the essence of statistical information as the official, proven information which characterizes the events and processes taking place in the economic, social and other spheres of life in the Ukraine. This information should be systematically published. The law also guarantees the availability of the unpublished statistical data, which are outside the frames of this law, to scientific research and other organizations concerned.

The state statistical bodies play a special role in the implementation of the Programme of Activities of the Council of Ministers of the Ukraine for 19951996, approved by the Ukrainian Parliament.

The Ministry of Statistics will participate in the preparation of selected legal acts and in the implementation of the Programme of Activities of the Government. It will also prepare the relevant documents to ensure the availability of public information about the implementation of this Programme. 